\title{
FAKTOR-FAKTOR YANG BERPENGARUH TERHADAP KEJADIAN PENYAKIT SKABIES PADA SANTRI DI PONDOK PESANTREN QOTRUN NADA CIPAYUNG DEPOK FEBRUARI TAHUN 2016
}

\author{
Hasna Ibadurrahmi* Silvia Veronica ${ }^{\star \star}$ Nunuk Nugrohowati* \\ *Program Studi S1 Kedokteran Umum, Fakultas Kedokteran UPN “Veteran” Jakarta \\ ${ }^{* *}$ Departemen Kulit Kelamin RSPAD Gatot Subroto \\ Jl. RS Fatmawati, Pondok Labu, Jakarta Selatan 12450, Telp. (021) 7656971 \\ Homepage: http://www.jurnal.fk.upnvj.ac.id
}

\begin{abstract}
ABSTRAK
Skabies merupakan penyakit kulit yang disebabkan oleh infestasi dan sensitisasi tungau Sarcoptes scabiei varietas hominis. Setiap santri yang tinggal di asrama pesantren memiliki peluang yang sama untuk terjadinya skabies. Karakteristik santri dan lingkungan kamar santri diduga berperan terhadap kejadian skabies. Penelitian ini bertujuan untuk mengetahui faktor apa yang paling berpengaruh terhadap kejadian penyakit skabies di Pondok Pesantren Qotrun Nada Cipayung, Depok tahun ajaran 2015/2016. Penelitian ini bersifat observasional analitik dengan desain cross sectional. Subjek penelitian ini adalah santri MTs dan MA Pondok Pesantren Qotrun Nada tahun ajaran 2015/2016 dengan jumlah sampel sebanyak 258 orang dan 30 kamar santri. Analisis data berdasarkan kejadian penyakit skabies menggunakan uji Chi-Square $(\mathrm{p}<0,05)$ dan dilanjutkan dengan uji multivariat regresi logistik. Dari hasil uji Chi-Square menunjukkan bahwa ada hubungan antara pengetahuan, sikap, perilaku santri, kepadatan penghuni, kelembaban udara, pencahayaan alami, suhu, dan ventilasi kamar santri terhadap kejadian penyakit skabies di Pondok Pesantren Qotrun Nada Cipayung, Depok. Dari hasil uji regresi logistik multivariat, karakteristik yang paling mempengaruhi kejadian penyakit skabies adalah perilaku santri dan kepadatan penghuni pada kamar santri.
\end{abstract}

Kata Kunci: Karakteristik, Skabies, Perilaku santri, Pondok pesantren

\section{ABSTRACT}

Scabies is a skin disease caused by mite infestation and sensitization Sarcoptes scabiei variety hominis. Every student who live in dormitories boarding school has the same opportunities for the occurrence of scabies. Students and environmental characteristics of the rooms thought to contribute to the incidence of scabies. This study aims to determine what factors most influence on the incidence of scabies disease at boarding Qotrun Nada Cipayung Depok academic year 2015/2016. This research was observational analytic with cross sectional design. The subjects were 258 students of MTs and MA Boarding school of Qotrun Nada academic year 2015/2016. Data analysis was based on the incidence of disease scabies using Chi-square test $(p<0,05)$ and followed by multivariate logistic regression. Chi-Square test results showed that there was influence among knowledge, attitudes, student behavior, density of occupant, humidity, lighting, temperature, and room ventilation students with the incidence of scabies disease at boarding Qotrun Nada Cipayung, Depok. Results of multivariate logistic regression analysis showed the most influences characteristics were student attitude and density of occupant.

Keywords: Characteristics, Scabies, Student attitude, Boarding school 


\section{PENDAHULUAN}

Setiap manusia berhak untuk sehat, baik sehat jasmani, rohani, maupun pikiran. Menurut WHO, sehat merupakan suatu keadaan yang sempurna baik secara fisik, mental, sosial, serta tidak hanya bebas dari penyakit/kelemahan yang memungkinkan hidup produktif secara sosial dan ekonomi.

Penyakit skabies merupakan penyakit kulit dengan insidensi dan prevalensi yang tinggi di seluruh dunia, terutama di daerah

beriklim tropis dan subtropis (Hilma \& Ghazali 2014, hlm.150).

Prevalensi skabies di seluruh dunia dilaporkan sekitar 300 juta kasus per tahun. Pada negara industri seperti di Jerman, skabies terjadi secara sporadik atau dalam bentuk endemik yang panjang. Prevalensi skabies di India 20,4\%, di Nigeria 28,6\%,

Australia dan Negara di Oceania dengan prevalensi 30\%, Malaysia sebesar 31\% (Setyaningrum n.d, hlm.2).

Prevalensi skabies di Indonesia sebesar 4,6\%$12,95 \%$ dan merupakan urutan ketiga dari 12 penyakit kulit tersering yang terjadi di masyarakat, terutama di daerah pemukiman padat penghuni seperti TPA (Taman Pendidikan Anak), penjara, barak, rumah susun, dan pondok pesantren (Al Audhah dkk. 2012, hlm.15).

Jenis kelamin mempengaruhi tingkat kejadian penyakit skabies. Hasil penelitian menunjukkan laki-laki cenderung lebih rentan terinfeksi skabies dengan prevalensi 58\% dibandingkan wanita, yaitu dengan prevalensi 42\% (Akmal dkk. 2013, hlm.165).

Hasil penelitian lain menunjukkan bahwa perempuan cenderung lebih rentan terinfeksi skabies dengan prevalensi $62,5 \%$ dibandingkan laki-laki, yaitu dengan prevalensi 37,5\% (Intan 2014, hlm.8-9). Usia mempengaruhi tingkat kejadian penyakit skabies. Tingkatprevalensi skabies lebih tinggi terjadi pada anak. Prevalensi skabies terjadi pada anak usia 12-14 tahun dan usia 15-17 tahun (Rohmawati 2010, hlm.40-41). Hasil penelitian menunjukkan bahwa perilaku kebersihan diri (personal hygiene) santri berpengaruh terhadap kejadian penyakit skabies, dengan hasil sebagai berikut: pengetahuan tentang kebersihan perseorangan 13,3\% kurang, sikap kebersihan perseorangan santri 16,7\% negatif, tindakan kebersihan perseorangan santri 83,3\% rendah (Akmal dkk. 2013, hlm.166).

Lingkungan fisik kamar santri berpengaruh terhadap kejadian penyakit skabies, seperti kelembaban $75 \%$ tidak baik, pencahayaan 70,8\%, suhu $83,3 \%$ tidak baik, berpengaruh terhadap kejadian penyakit skabies. Ventilasi ruang kamar santri pun berpengaruh terhadap kejadian penyakit skabies, karena ventilasi merupakan salah satu parameter yang paling berperan dalam penularan penyakit skabies (Lathifa 2014, hlm.62-63).

Selain itu, prevalensi skabies yang tinggi umumnya ditemukan di lingkungan dengan kepadatan penghuni dan kontak interpersonal tinggi, seperti penjara, panti asuhan, dan pondok pesantren (Ratnasari \& Saleha 2014, hlm.2).

Hal ini menjadikan besarnya kemungkinan terjadinya kontak langsung antara penderita skabies dengan santri yang sehat sehingga memicu terjadinya peningkatan jumlah penderita skabies.Di Indonesia, sebagai negara dengan jumlah penduduk muslim terbanyak di dunia, terdapat 14.798 pondok pesantren dengan prevalensi skabies cukup tinggi (Ratnasari \& Saleha 2014, hlm.2).

Pesantren Qotrun Nada merupakan pondok pesantren di Depok yang memiliki jumlah santri terbanyak se-Depok, yaitu sebanyak 1489 santri. Hal inilah yang dapat meningkatkan kejadian penyakit skabies karena tingginya keterpaparan antara satu santri dengan santri lainnya (Pondok Pesantren Qotrun Nada 2016, hlm.1).

Berdasarkan latar belakang di atas, peneliti tertarik untuk melakukan penelitian tentang "Faktor-faktor yang berpengaruh terhadap kejadian penyakit skabies pada santri di Pondok Pesantren Qotrun Nada Cipayung, Depok Bulan Februari tahun 2016".

\section{METODE PENELITIAN}

Jenis penelitian ini adalah analitik observasional dengan rancangan cross sectional.Penelitian ini terdiri dari sepuluh variabel yang terbagi menjadi 
dua kelompok, yaitu kelompok berdasarkan karakteristik yang terdiri dari variabel jenis kelamin, usia, pengetahuan, sikap, dan perilaku. Kelompok kedua yaitu kelompok berdasarkan lingkungan fisik kamar santri yang terdiri dari variabel kepadatan penghuni, kelembaban udara, pencahayaan alami, suhu, dan ventilasi.

Alasan sepuluh variabel dibagi menjadi dua kelompok dikarenakan sampel pada kedua kelompok memiliki jumlah yang berbeda sehingga tidak dapat diolah secara bersamasama dalam pengolahan data. Selain itu, subjek yang diteliti juga berbeda, pada kelompok berdasarkan karakteristik yang diteliti adalah santri, sedangkan pada kelompok lingkungan fisik kamar santri yang diteliti adalah kamar santri. Penelitian dilakukan selama dua hari di Pondok Pesantren Qotrun Nada, Kecamatan Cipayung Kota Depok pada Bulan Februari tahun 2016.

Pada penelitian ini, populasi dibagi menjadi dua, yaitu populasi santri kelas 1, 2, dan 3 (MTs dan MA) yang berjumlah 1489 santri dengan teknik sampling yaituproportional stratified random samplingsehingga jumlah sampel penelitian yang dibutuhkan sebanyak 286 santri. Populasi kedua ialah kamar santri dengan teknik sampling yaitutotal samplingsehingga jumlah sampel penelitian yang dibutuhkan adalah sebanyak 30 kamar.

Jenis data yang digunakan adalah data primer dan sekunder. Data primer variabel karakteristik santri dikumpulkan dengan menggunakan kuesioner yang sudah di uji validitas dan reliabilitasnya, sedangkan data primer variabel lingkungan fisik kamar santri dengan pengukuran langsungmenggunakan masing-masing alat sesuai fungsinya. Data sekunder didapatkan dari Departemen Agama Depok mengenai jumlah kasus skabies pada pondok pesantren di Depok dan dari Pondok Pesantren Qotrun Nada untuk data profil pesantren, absensi kelas, dan absensi kamar santri.

Penelitian ini menggunakan analisis data univariat, bivariat, dan multivariat.Analisis univariat digunakan untukmengetahui distribusi frekuensi variabel independen dan dependen yang diteliti. Analisis bivariat digunakan untuk mengetahui ada tidaknya hubungan antara variabel independen.Pada penelitian ini, seluruh variabel yang diteliti merupakan data kategorik tidak berpasangan dengan tabel $2 \times 2$ dan tabel bxk $(3 \times 2)$, sehingga uji yang dilakukan adalah uji Chi square. Analisis multivariat bertujuan untuk mengetahui variabel independen mana yang paling mempengaruhi variabel dependen. Analisis ini menggunakan uji regresi logistik multivariat.

\section{HASIL DAN PEMBAHASAN}

\section{Hasil Analisis Univariat}

Analisis ini dilakukan untuk mengetahui gambaran dan distribusi dari variabel-variabel penelitian, yaitu kejadian penyakit skabies sebagai variabel dependen dan jenis kelamin, usia, pengetahuan, sikap, perilaku, kepadatan penghuni, kelembaban udara, pencahayaan alami, suhu, dan ventilasi sebagai variabel independen. Adapun analisis univariat dari penelitian ini dijelaskan menurut masing-masing variabel, yaitu:

Tabel 1 Distribusi Karakteristik Santri Pondok Pesantren Qotrun Nada Tahun Ajaran 2015/2016

\begin{tabular}{|c|c|c|}
\hline Kategori & Jumlah & Presentase (\%) \\
\hline \multicolumn{3}{|c|}{ Jenis Kelamin } \\
\hline Perempuan & 168 & 65,1 \\
\hline Laki-laki & 90 & 34,9 \\
\hline \multicolumn{3}{|c|}{ Usia } \\
\hline 12-14 tahun & 145 & 56,2 \\
\hline $15-17$ tahun & 113 & 43,8 \\
\hline \multicolumn{3}{|c|}{ Pengetahuan } \\
\hline Kurang & 94 & 36,4 \\
\hline Cukup & 87 & 33,7 \\
\hline Baik & 77 & 29,8 \\
\hline \multicolumn{3}{|c|}{ Sikap } \\
\hline Kurang & 104 & 40,3 \\
\hline Cukup & 81 & 31,4 \\
\hline Baik & 73 & 28,3 \\
\hline \multicolumn{3}{|c|}{ Perilaku } \\
\hline Kurang & 114 & 44,2 \\
\hline Cukup & 90 & 34,9 \\
\hline Baik & 54 & 20,9 \\
\hline
\end{tabular}




\section{a. Jenis Kelamin}

Dari hasil penelitian ini diketahui bahwa kelompok santri terbanyak berjenis kelamin perempuan, yaitu sebesar $65,1 \%$ dengan perbedaan persentase sebesar 30,2\%. Hal ini dikarenakan proporsi jumlah santri secara keseluruhan lebih banyak perempuan daripada laki-laki di Pondok Pesantren Qotrun Nada, yaitu sebanyak 872 santri perempuan dan 617 santri laki-laki (Pondok Pesantren Qotrun Nada 2016, hlm.1).

\section{b. Usia}

Dari hasil penelitian ini diketahui bahwa kelompok santri terbanyak berusia 12-14 tahun, yaitu sebesar $56,2 \%$ dengan perbedaan persentase sebesar $12,4 \%$. Hal ini dikarenakan jumlah santri MTs di Pondok Pesantren Qotrun Nada lebih banyak daripada santri MA selama tiga tahun terakhir, yaitu sebanyak 883 santri MTs dan 606 santri MA pada tahun ajaran 2015/2016 (Pondok Pesantren Qotrun Nada 2016, hlm.1).

\section{c. Pengetahuan}

Dari hasil penelitian ini diketahui bahwa sebagian besar santri di Pondok Pesantren Qotrun Nada memiliki pengetahuan kurang mengenai skabies, yaitu sebesar 36,4\%. Hal ini dikarenakan sebagian besar dari responden masih berusia 12-14 tahun dan masih duduk di bangku sekolah menengah pertama (MTs) sehingga ilmu atau pendidikan yang mereka dapat belum seberapa jika dibandingkan dengan responden yang berumur 15-17 tahun atau yang sudah duduk di bangku sekolah menengah atas (MA), dimana jumlah santri MTs sebanyak 167 dari 883 santri yang dijadikan responden, sedangkan jumlah santri MA sebanyak 119 dari 606 santri yang dijadikan responden (Pondok Pesantren Qotrun Nada 2016, hlm.1).

\section{d. Sikap}

Dari hasil analisis univariat diketahui bahwa sebagian besar santri di Pondok Pesantren Qotrun Nada memiliki sikap kurang terhadap kebersihan mengenai skabies, yaitu sebesar 40,3\%. Hal ini dikarenakan hubungan antara pengetahuan yang kurang dapat memengaruhi hasil sikap yang ada dalam diri seseorang.

\section{e. Perilaku}

Dari hasil penelitian ini diketahui bahwa sebagian besar santri di Pondok Pesantren Qotrun Nada memiliki perilaku kurang mengenai skabies, yaitu sebesar $37,1 \%$. Hal ini dikarenakan hubungan antara pengetahuan dan sikap yang kurang dapat memengaruhi perilaku yang ada dalam diri seseorang (Notoatmodjo 2007, hlm..139).

Tabel 2 Distribusi Lingkungan Fisik Kamar Santri Pondok Pesantren Qotrun Nada Tahun Ajaran 2015/2016

\begin{tabular}{|c|c|c|}
\hline Kategori & Jumlah & $\begin{array}{c}\text { Presentas } \\
\text { e }(\%)\end{array}$ \\
\hline \multicolumn{3}{|c|}{ Kepadatan Penghuni } \\
\hline $\begin{array}{l}\text { Tidak Memenuhi } \\
\text { Syarat } \\
\text { Memenuhi Syarat }\end{array}$ & $\begin{array}{l}22 \\
8\end{array}$ & $\begin{array}{l}73,3 \\
26,7\end{array}$ \\
\hline \multicolumn{3}{|c|}{ Kelembaban Udara } \\
\hline $\begin{array}{l}\text { Tidak Memenuhi } \\
\text { Syarat } \\
\text { Memenuhi Syarat }\end{array}$ & $\begin{array}{l}19 \\
11\end{array}$ & 63,3 \\
\hline \multicolumn{3}{|c|}{ Pencahayaan Alami } \\
\hline $\begin{array}{l}\text { Tidak Memeauhi } \\
\text { Syarat } \\
\text { Memenuhi Syarat }\end{array}$ & $\begin{array}{l}19 \\
11\end{array}$ & 63,3 \\
\hline \multicolumn{3}{|c|}{ Suhu } \\
\hline $\begin{array}{l}\text { Tidak Memeauhi } \\
\text { Syarat } \\
\text { Memenuhi Syarat }\end{array}$ & $\begin{array}{l}16 \\
14\end{array}$ & 46,7 \\
\hline \multicolumn{3}{|c|}{ Ventilasi } \\
\hline $\begin{array}{l}\text { Tidak Memenuhi } \\
\text { Syarat } \\
\text { Memenuhi Syarat }\end{array}$ & 23 & 76,7 \\
\hline
\end{tabular}

\section{f. Kepadatan Penghuni}

Kepadatan penghuni adalah perbandingan antara luas lantai rumah dengan jumlah anggota keluarga dalam suatu rumah tinggal. Secara umum, penilaian kepadatan penghuni dengan menggunakan ketentuan standar minimum, yaitu kepadatan penghuni yang memenuhi syarat kesehatan diperoleh dari hasil bagi antara luas lantai dengan jumlah penghuni $8 \mathrm{~m} 2$ /orang (Indonesia. 2011, hlm.15).

Hasil analisis univariat terhadap kepadatan penghuni didapatkan bahwa sebagian besar kamar memiliki kepadatan penghuni yang tidak memenuhi syarat kesehatan, yaitu dengan persentase sebesar 73,3\%. Hal ini dikarenakan 
tidak proporsionalnya antara luas kamar dengan jumlah santri yang menghuni kamar.

\section{g. Kelembaban Udara}

Kelembaban udara adalah persentase jumlah kandungan air dalam udara. Secara umum, penilaian kelembaban dalam rumah dengan menggunakan hygrometer dengan kriteria memenuhi syarat kesehatan yaitu dengan kelembaban 40-70\% (Indonesia. 2011, hlm.14). Hasil analisis univariat terhadap kelembaban udara di kamar santri, didapatkan bahwa sebagian besar kamar memiliki kelembaban yang tidak memenuhi syarat kesehatan, yaitu dengan persentase sebesar 63,3\%. Kelembaban udara dalam suatu ruangan dipengaruhi oleh beberapa faktor, salah satunya pencahayaan, suhu, dan pergerakan angin. Ketidaksesuaian salah satu faktor tersebut dengan syarat kondisi termal ruangan, dapat menggeser persentase kelembaban udara di kamar santri sehingga kelembaban menjadi sedikit tinggi.

\section{h. Pencahayaan Alami}

Pencahayaan alami ruangan adalah penerangan yang bersumber dari sinar matahari (alami), yaitu semua jalan yang memungkinkan untuk masuknya cahaya alamiah, misalnya melalui jendela atau genting kaca. Syarat pencahayaan alam dan/atau buatan langsung maupun tidak langsung dapat menerangi seluruh ruangan minimal intensitasnya 60 lux dan tidak menyilaukan. Pencahayaan yang memenuhi syarat kesehatan berkisar antara intensitas cahaya 60-120 lux (Indonesia. 2011, hlm.14).

Hasil analisis univariat terhadap pencahayaan alami didapatkan bahwa sebagian besar kamar memiliki pencahayaan yang tidak memenuhi syarat kesehatan, dengan persentase sebesar $63,3 \%$. Intensitas sinar matahari berubah sesuai dengan waktu, musim, dan lokasi. Faktor yang memengaruhi kualitas penerangan yaitu perbandingan luas lubang cahaya dan luas lantai, bentuk lubang cahaya, letak lubang cahaya, dan refleksi cahaya di dalam ruangan. Untuk meningkatkan kualitas penerangan alami siang hari di dalam ruangan, hendaknya ruangan menerima cahaya lebih dari satu arah (Hananto 2010, hlm.15-16).

\section{i. Suhu}

Suhu adalah panas atau dinginnya udara yang dinyatakan dengan satuan derajat tertentu. Secara umum, penilaian suhu rumah dengan menggunakan thermometer ruangan dengan suhu kamar yang memenuhi syarat kesehatan adalah antara $18-30^{\circ} \mathrm{C}$.

Hasil analisis univariat terhadap suhu didapatkan bahwa sebagian besar kamar memiliki suhu yang tidak memenuhi syarat kesehatan, yaitu dengan persentase sebesar 60\%. Hal ini dikarenakan beberapa faktor yang memengaruhi suhu dalam ruangan, salah satunya yaitu lamanya penyinaran matahari atau pencahayaan. Pencahayaan yang kurang menyebabkan rendahnya suhu dalam kamar santri (Kholid 2010, hlm.6).

\section{j. Ventilasi}

Ventilasi adalah usaha untuk memenuhi kondisi atmosfer yang menyenangkan dan menyehatkan manusia. Secara umum, penilaian ventilasi rumah dengan cara membandingkan antara luas ventilasi dan luas lantai rumah. Menurut indikator pengawasan rumah, luas ventilasi yang memenuhi syarat kesehatan adalah $10 \%$ luas lantai rumah dan luas ventilasi yang tidak memenuhi syarat kesehatan adalah $<10 \%$ luas lantai rumah (Indonesia 2011, hlm.15).

Hasil analisis univariat terhadap ventilasi didapatkan bahwa sebagian besar kamar memiliki ventilasi yang tidak memenuhi syarat kesehatan, yaitu dengan persentase sebesar $60 \%$. Hal ini dikarenakan kurangnya ventilasi yang berfungsi baik pada sebagian besar kamar santri, seperti ditutup kertas atau kain sehingga menghalangi udara untuk masuk ke dalam ruangan dengan baik, sehingga sirkulasi udara tidak berjalan dengan baik.

\section{Hasil Analisis Bivariat}

Analisis ini dilakukan untuk mengetahui hubungan antara variabel yang diteliti yaitu antara variabel independen seperti jenis kelamin, usia, pengetahuan, sikap, perilaku, kepadatan penghuni, kelembaban udara, pencahayaan alami, suhu, dan ventilasi dengan variabel dependen yaitu penyakit skabies dengan 
menggunakan uji Chi-Square untuk melihat ada tidaknya hubungan antara variabel independen dan variabel dependen berdasarkan batas nilai kemaknaan alpha 0,05 , artinya bila pvalue $<0,05$ maka disimpulkan ada hubungan antara variabel independen dengan variabel dependen.

Tabel 3 Hasil Analisis Bivariat Hubungan Jenis Kelamin, Usia, Pengetahuan, Sikap, Perilaku, Kepadatan Penghuni, Kelembaban Udara, Pencahayaan Alami, Suhu, dan Ventilasi Terhadap Kejadian PenyakitSkabies

\begin{tabular}{|c|c|c|c|c|c|}
\hline \multicolumn{6}{|c|}{$\begin{array}{l}\text { Hubungan Jenis Kelamin Terhadap Kejadian } \\
\text { Penyakit Skabies }\end{array}$} \\
\hline & $\mathbf{S}$ & $\%$ & TS & $\%$ & P Value \\
\hline Perempuan & 90 & 53,6 & 78 & 46,4 & 0,584 \\
\hline Laki-laki & 45 & 50,0 & 45 & 50,0 & \\
\hline Hubungan & \multicolumn{5}{|c|}{ Tidak Ada } \\
\hline \multicolumn{6}{|c|}{$\begin{array}{c}\text { Hubungan Usia Terhadap Kejadian Penyakit } \\
\text { Skabies }\end{array}$} \\
\hline & $\mathrm{S}$ & $\%$ & TS & $\%$ & P Value \\
\hline 12-14 tahun & 80 & 55,2 & 65 & 44,8 & 0,300 \\
\hline 15-17 tahun & 55 & 48,7 & 58 & 51,3 & \\
\hline Hubungan & \multicolumn{5}{|c|}{ Tidak Ada } \\
\hline \multicolumn{6}{|c|}{$\begin{array}{c}\text { Hubungan Pengetahuan Terhadap Kejadian } \\
\text { Penyakit Skabies }\end{array}$} \\
\hline & $\mathrm{S}$ & $\%$ & TS & $\%$ & P Value \\
\hline Kurang & 57 & 60,6 & 37 & 39,4 & 0,045 \\
\hline Cukup & 46 & 52,9 & 41 & 47,1 & \\
\hline Baik & 32 & 41,6 & 45 & 58,4 & \\
\hline Hubungan & \multicolumn{5}{|c|}{ Ada } \\
\hline \multicolumn{6}{|c|}{$\begin{array}{c}\text { Hubungan Sikap Terhadap Kejadian Penyakit } \\
\text { Skabies }\end{array}$} \\
\hline & $\mathrm{S}$ & $\%$ & $\mathrm{TS}$ & $\%$ & P Value \\
\hline Kurang & 64 & 61,5 & 40 & 38,5 & 0,017 \\
\hline Cukup & 42 & 51,9 & 39 & 48,1 & \\
\hline Baik & 29 & 39,7 & 44 & 60,3 & \\
\hline Hubungan & \multicolumn{5}{|c|}{ Ada } \\
\hline \multicolumn{6}{|c|}{$\begin{array}{l}\text { Hubungan Perilaku Terhadap Kejadian Penyakit } \\
\text { Skabies }\end{array}$} \\
\hline & $\mathrm{S}$ & $\%$ & TS & $\%$ & PValue \\
\hline Kurang & 60 & 52,6 & 54 & 47,4 & 0,001 \\
\hline Cukup & 58 & 64,4 & 32 & 35,6 & \\
\hline Baik & 17 & 31,5 & 37 & 68,5 & \\
\hline Hubungan & \multicolumn{5}{|c|}{ Ada } \\
\hline
\end{tabular}

\begin{tabular}{|c|c|c|c|c|c|}
\hline \multicolumn{6}{|c|}{$\begin{array}{c}\text { Hubungan Kepadatan Penghuni Terhadap Kejadian } \\
\text { Penyakit Skabies }\end{array}$} \\
\hline & $\mathbf{S}$ & $\%$ & TS & $\%$ & P Value \\
\hline Tidak & 15 & 68,2 & 7 & 31,8 & \\
\hline $\begin{array}{l}\text { Memenuhi } \\
\text { Syarat }\end{array}$ & & & & & 15,000 \\
\hline $\begin{array}{c}\text { Memenuhi } \\
\text { Syarat }\end{array}$ & 1 & 12,5 & 7 & 87,5 & \\
\hline
\end{tabular}

\begin{tabular}{|c|c|c|c|c|c|}
\hline \multicolumn{6}{|c|}{$\begin{array}{c}\text { Hubungan Kelembaban Udara Terhadap Kejadian } \\
\text { Penyakit Skabies }\end{array}$} \\
\hline & $\mathbf{S}$ & $\%$ & TS & $\%$ & PValue \\
\hline Tidak & 13 & 68,4 & 6 & 31,6 & 0,029 \\
\hline $\begin{array}{l}\text { Memenuhi } \\
\text { Syarat }\end{array}$ & & & & & \\
\hline $\begin{array}{l}\text { Memenuhi } \\
\text { Syarat }\end{array}$ & 3 & 27,3 & 8 & 72,7 & \\
\hline Hubungan & \multicolumn{5}{|c|}{ Ada } \\
\hline
\end{tabular}

Hubungan Pencahayaan Alami Terhadap Kejadian

\begin{tabular}{|c|c|c|c|c|c|}
\hline \multicolumn{6}{|c|}{ Penyakit Skabies } \\
\hline & $\mathrm{S}$ & $\%$ & TS & $\%$ & $\overline{\text { PValue }}$ \\
\hline Tidak & 13 & 68,4 & 6 & 31,6 & 0,029 \\
\hline $\begin{array}{c}\text { Memenuhi } \\
\text { Syarat }\end{array}$ & & & & & \\
\hline $\begin{array}{c}\text { Memenuhi } \\
\text { Syarat }\end{array}$ & 3 & 27,3 & 8 & 72,7 & \\
\hline Hubungan & & & & & \\
\hline
\end{tabular}

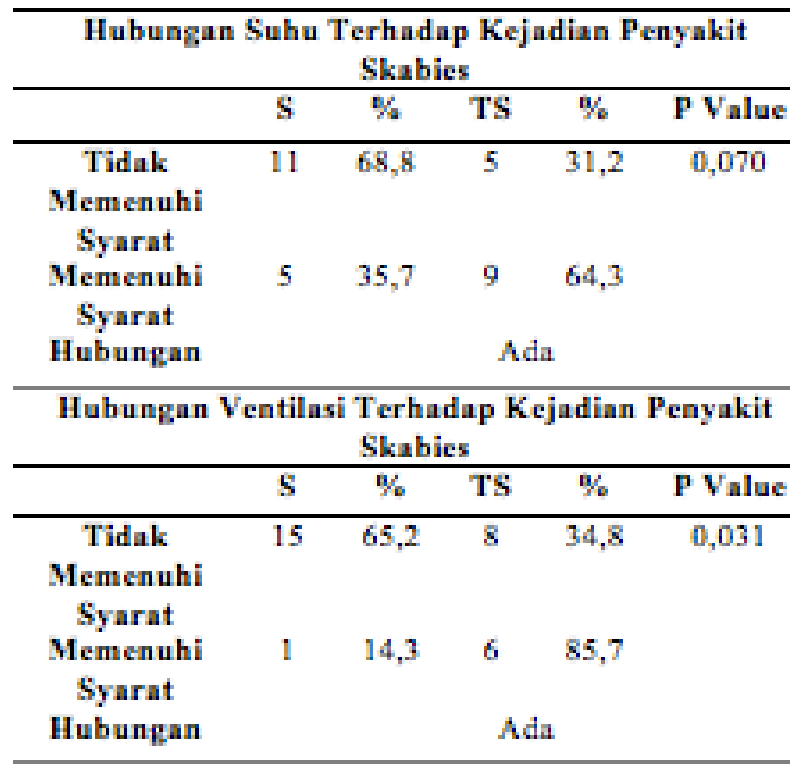

Sumber: Data primer, 2016

\section{a. Jenis Kelamin}

Hasil analisis bivariat menunjukkan bahwa tidak terdapat hubungan antara jenis kelamin dengan kejadian penyakit skabies pada santri di Pondok Pesantren Qotrun Nada tahun ajaran 2015/2016, dengan nilai $\mathrm{p}$ value $>0,05$ yaitu sebesar 0,584 . Data penelitian menunjukkan bahwa santri dengan jenis kelamin perempuan lebih banyak 
yang menderita skabies dengan persentase sebesar $53,6 \%$.

Penelitian ini sejalan dengan penelitian yang dilakukan oleh Ratnasari (2014, hlm.254) yang menyebutkan bahwa terdapat hubungan yang bermakna antara jenis kelamin terhadap kejadian penyakit skabies.Penelitian ini tidak sejalan dengan penelitian yang dilakukan oleh Al Udhah dkk (2012, hlm.17) yang menyebutkan bahwa laki-laki lebih berisiko terkena skabies sebanyak 24 kali dibandingkan perempuan.

Hal ini menunjukkan bahwa baik jenis kelamin laki-laki maupun perempuan memiliki peluang yang sama untuk mengalami skabies (Handoko 2005, hlm.3).Selain itu, jumlah kamar yang tidak sesuai dengan santri yang ada, semakin meningkatkan risiko terjadinya kejadian penyakit skabies sehingga terjadi kepadatan penghuni dalam kamar santri tersebut. Kepadatan penghuni ini menjadi salah satu faktor yang berperan dalam penularan penyakit skabies (Ma’rufi 2005, hlm.5).

\section{b. Usia}

Hasil analisis bivariat menunjukkan bahwa tidak terdapat hubungan antara usia dengan kejadian penyakit skabies pada santri di Pondok Pesantren Qotrun Nada tahun ajaran 2015/2016, dengan nilai $p$ value $>0,05$ yaitu sebesar 0,300 . Data penelitian menunjukkan bahwa santri dengan usia 12-14 tahun lebih banyak yang menderita skabies dengan persentase sebesar 55,2\%.

Penelitian ini sejalan dengan penelitian yang dilakukan oleh Windi (2014, hlm.5) yang menyebutkan bahwa terdapat hubungan bermakna antara usia terhadap kejadian penyakit skabies.Hasil penelitian ini tidak sejalan dengan penelitian yang dilakukan oleh Azizah (2012, hlm.37) yang menyebutkan bahwa terdapat hubungan antara usia dengan kejadian penyakit skabies, yaitu pada santri usia 13-15 tahun $(56,82 \%)$.

Usia responden merupakan karakteristik yang membedakan tingkat kedewasaan seseorang. Usia seseorang demikian besarnya dalam memengaruhi pengetahuan, sikap, dan perilaku. Dalam kaitannya dengan kejadian skabies pada seseorang, pengalaman keterpaparan sangat berperan karena mereka yang berumur lebih tinggi dan mempunyai pengalaman terhadap skabies berpotensi lebih baik dalam mengetahui cara pencegahan serta penularan penyakit skabies.Di beberapa negara yang sedang berkembang, prevalensi skabies cenderung tinggi pada anak-anak serta remaja (Handoko 2005, hlm.3).

\section{c. Pengetahuan}

Hasil analisis bivariat menunjukkan bahwa pengetahuan memengaruhi kejadian penyakit skabies pada santri di Pondok Pesantren Qotrun Nada tahun ajaran 2015/2016, dengan $p$ value sebesar $0,045(\mathrm{p}<0,05)$. Data penelitian menunjukkan bahwa santri dengan pengetahuan kurang lebih banyak yang menderita skabies dengan persentase sebesar $60,6 \%$.

Hasil penelitian ini sejalan dengan penelitian Rohmawati (2010, hlm.44)yang menyebutkan bahwa dari 155 santri $(81,58 \%)$ santri berpengetahuan kurang lebih banyak yang menderita skabies. Hal ini juga didukung penelitian Hilma (2014, hlm.151) yang menyebutkan bahwa prevalensi skabies lebih tinggi terjadi pada santri dengan pengetahuan kurang, yaitu dari 46 santri yang berpengetahuan kurang, 28 santri menderita skabies (60,9\%). Penelitian ini tidak sejalan dengan penelitian yang dilakukan Lathifa (2014, hlm.65) yang menyebutkan bahwa tidak ada hubungan yang bermakna antara pengetahuan dengan kejadian penyakit skabies.

Pengetahuan santri mengenai penyakit skabies disebutkan dalam kategori kurang, yaitu didasarkan dari hasil skoring sebesar $<60$ pada kuesioner yang diisi oleh responden. Pengetahuan dapat diketahui jika seseorang telah berhubungan dengan objek tersebut yang mana sebagian besar pengetahuan dapat diperoleh dari melihat dan mendengar. Pengetahuan merupakan awal pengenalan terhadap suatu objek yang diamati, sehingga jika pengetahuan kurang baik terhadap suatu objek maka akan memengaruhi perilaku yang akan dilakukan. Masih banyaknya santri yang tidak tahu mengenai cara penularan skabies berdampak pada kontinuitas penyakit tersebut di kalangan santri (Notoatmodjo 2007, hlm.141). 


\section{d. Sikap}

Hasil analisis bivariat menunjukkan bahwa sikap memengaruhi kejadian penyakit skabies pada santri di Pondok Pesantren Qotrun Nada tahun ajaran 2015/2016, dengan p value sebesar 0,017 $(\mathrm{p}<0,05)$. Data penelitian menunjukkan bahwa santri dengan sikap kurang lebih banyak yang menderita skabies dengan persentase sebesar $61,5 \%$.

Hasil penelitian ini sejalan dengan penelitian Nugraheni (2008, hlm.12) yang menyebutkan bahwa dari 155 santri $(81,58 \%)$ santri dengan pengetahuan kurang menderita skabies. Hal ini juga didukung penelitian (Hilma 2014, hlm.14) yang menyebutkan bahwa prevalensi skabies lebih tinggi terjadi pada santri dengan pengetahuan kurang, yaitu dari 53 santri yang memiliki sikap kurang, 49 santri menderita skabies $(92,4 \%)$.

Sikap santri mengenai penyakit skabies disebutkan dalam kategori kurang, yaitu didasarkan dari hasil skoring sebesar $<45$ pada kuesioner yang diisi oleh responden. Begitu pula dengan keterikatan pertemanan yang dapat membuahkan sikap yang kurang akibat pengaruh temannya yang memiliki sikap kurang, karena antar teman dapat saling memengaruhi dalam bagaimana bersikap.

Menurut Azwar (2000) salah satu faktor yang dapat memengaruhi sikap adalah pengaruh orang lain yang dianggap penting. Orang lain yang berada di sekitar kita merupakan salah satu diantara komponen sosial, kaitannya dengan santri, teman dekat/teman sebaya merupakan salah satu orang yang dianggap penting dan berpengaruh. Di lingkungan Pondok Pesantren, teman sebaya adalah orang yang sangat berpengaruh selain guru atau Kyai yang berada di Pondok Pesantren karena merupakan teman di lingkungan sekolah dan lingkungan tempat tinggal. Oleh karena itu, jika seseorang teman memiliki sikap yang kurang dalam menjaga kebersihan dirinya, tidak menutup kemungkinan dapat memengaruhi teman yang lainnya (Nurliana \& Arina n.d, hlm.181).

\section{e. Perilaku}

Hasil analisis bivariat menunjukkan bahwa perilaku memengaruhi kejadian penyakit skabies pada santri di Pondok Pesantren Qotrun Nada tahun ajaran 2015/2016, dengan persentase sebesar 0,000 ( $\mathrm{p}<0,05)$. Data penelitian menunjukkan bahwa santri dengan perilaku kurang lebih banyak yang menderita skabies, yaitu dengan persentase sebesar 75,5\%.

Hasil penelitian ini sejalan dengan penelitian yang dilakukan oleh Ma'rufi (2005) dalam Rohmawati (2010, hlm.49) yang menyebutkan bahwa terdapat hubungan yang bermakna antara perilaku santri terhadap kejadian penyakit skabies. Penelitian ini juga didukung oleh penelitian yang dilakukan oleh Akmal (2013, hlm.166) yang menyebutkan bahwa terdapat hubungan yang bermakna antara perilaku santri terhadap kejadian penyakit skabies. Penelitian ini tidak sejalan dengan penelitian yang dilakukan oleh Al Audhah dkk. (2012, hlm.19) yang menyebutkan bahwa tidak terdapat hubungan yang bermakna antara perilaku santri terhadap kejadian penyakit skabies.

Perilaku santri mengenai penyakit skabies disebutkan dalam kategori kurang, yaitu didasarkan dari hasil skoring kuesioner dengan menjawab $<12$ soal atau mendapat skor nilai $<60$. Perilaku kebersihan diri seseorang terhadap kejadian penyakit menjadi salah satu faktor yang berperan dalam penularan penyakit skabies (Ma'rufi 2005, hlm.16).

Hal ini sesuai dengan teori Wahid (2009) yang menyatakan bahwa penularan penyakit skabies dapat terjadi melalui kontak langsung, misalnya berjabat tangan, tidur bersama dalam satu tempat tidur, dan hubungan seksual (Adiyaningsih 2012, hlm.6).

\section{f. Kepadatan Penghuni}

Hasil analisis bivariat terhadap variabel kepadatan penghuni menunjukkan bahwa kepadatan penghuni memengaruhi kejadian penyakit skabies pada santri di Pondok Pesantren Qotrun Nada tahun ajaran 2015/2016, dengan $p$ value sebesar $0,007(\mathrm{p}<0,05)$. Data penelitian menunjukkan bahwa kepadatan penghuni kamar yang tidak memenuhi syarat kesehatan terhadap santri yang menderita skabies dengan persentase sebesar $68,2 \%$.

Hasil penelitian ini sejalan dengan penelitian Hilmi (2011, hlm.17) yang menyebutkan bahwa 
tingginya prevalensi skabies di suatu pesantren di Jakarta Timur, yaitu dengan persentase sebesar 51,6\%. Penelitian ini juga didukung oleh penelitian yang dilakukan Al Audhah dkk. (2012, hlm.18) yang menyebutkan bahwa terdapat hubungan yang bermakna antara kepadatan penghuni dengan terjadinya skabies. Hasil penelitian ini tidak sejalan dengan penelitian yang dilakukan oleh Hilma (2014, hlm.153) yang menyebutkan bahwa variabel tingkat kepadatan penghuni tidak memiliki hubungan yang bermakna dengan kejadian penyakit skabies.

Tingginya kepadatan penghuni menyebabkan kontak fisik antar santri menjadi tinggi pula, sehingga memudahkan penularan skabies. Inilah salah satu faktor yang menyebabkan tingginya kejadian penyakit skabies di pondok pesantren yang memungkinkan untuk terjadi peningkatan di masa yang akan datang apabila tidak ditindaklanjuti dengan baik untuk mengurangi kepadatan penghuni dalam kamar santri tersebut. Kepadatan penghuni merupakan variabel pada kamar santri yang paling berpengaruh.

\section{g. Kelembaban Udara}

Hasil analisis bivariat terhadap variabel kelembaban udara menunjukkan bahwa kelembaban udara memengaruhi kejadian penyakit skabies pada santri di Pondok Pesantren Qotrun Nada tahun ajaran 2015/2016, dengan $p$ value sebesar $0,029(\mathrm{p}<0,05)$. Data penelitian menunjukkan bahwa kelembaban udara dalam kamar yang tidak memenuhi syarat kesehatan terhadap santri yang menderita skabies cukup tinggi dengan persentase sebesar $68,4 \%$.

Hal ini sejalan dengan penelitian Windi (2014, hlm.6) yang menyebutkan bahwa kelembaban udara merupakan faktor risiko bagi kejadian penyakir skabies. Apabila ruangan para santri kelembabannya semakin tidak baik maka akan berisiko 15 kali lipat terkena skabies dibanding dengan santri yang berada di ruangan dengan kelembaban baik. Penelitian ini juga didukung dengan penelitian yang dilakukan oleh Ma'rufi dkk. (2005, hlm.15) yang menyebutkan bahwa terdapat hubungan bermakna antara kelembaban dengan kejadian penyakit skabies.

Kelembaban yang baik untuk kesehatan adalah
40-70\%. Apabila kelembaban tidak sesui dengan syarat tersebut, maka dapat berdampak bagi kesehatan manusia yang menetap dalam ruangan tersebut. Pada kamar santri yang memiliki kelembaban tidak memenuhi syarat kesehatan, menjadi peluang bagi agen Sarcoptes scabiei untuk tetap hidup dan berkembang biak, sehingga peluang untuk terjadinya penyakit skabies pada santri dalam kamar tersebut semakin meningkat. Hal inilah yang memberikan kesimpulan bahwa semakin buruknya kelembaban udara dalam ruangan, akan berpengaruh terhadap peningkatan kejadian penyakit skabies.

\section{h. Pencahayaan Alami}

Hasil analisis bivariat terhadap variabel pencahayaan alami menunjukkan bahwa pencahayaan alami memengaruhi kejadian penyakit skabies pada santri di Pondok Pesantren Qotrun Nada tahun ajaran 2015/2016, dengan $p$ value sebesar 0,029 ( $\mathrm{p}<0,05)$. Data penelitian menunjukkan bahwa kelembaban udara dalam kamar yang tidak memenuhi syarat kesehatan terhadap santri yang menderita skabies cukup tinggi dengan persentase sebesar $68,4 \%$.

Hal ini sejalan dengan penelitian Windi (2014, hlm.10) yang menyebutkan bahwa pencahayaan merupakan faktor risiko bagi kejadian skabies. Apabila ruangan para santri pencahayaannya semakin tidak baik maka akan berisiko lima kali lipat terkena skabies dibanding dengan santri yang berada di ruangan dengan pencahayaan baik. Jumlah cahaya yang masuk memengaruhi kelembaban kamar yang berpengaruh terhadap habitat dan perkembangbiakan Sarcoptes scabiei. Semakin buruknya pencahayaan ruangan, akan berpengaruh terhadap peningkatan kejadian penyakit skabies.

\section{i. Suhu}

Hasil analisis bivariat terhadap variabel suhu menunjukkan bahwa suhu memengaruhi kejadian penyakit skabies pada santri di Pondok Pesantren Qotrun Nada tahun ajaran 2015/2016, dengan $\mathrm{p}$ value sebesar $0,011(\mathrm{p}<0,05)$. Data penelitian menunjukkan bahwa suhu dalam kamar yang tidak memenuhi syarat kesehatan yang menderita skabies cukup tinggi dengan persentase sebesar $72,2 \%$. 
Hal ini sejalan dengan penelitian Windi (2014, hlm.10) yang menyebutkan bahwa suhu merupakan faktor risiko bagi kejadian skabies. Apabila ruangan para santri suhunya semakin tidak baik makan akan berisiko sepuluh kali lipat terkena skabies dibanding dengan santri yang berada di ruangan dengan suhu baik. Semakin buruk suhu ruangan akan berpengaruh terhadap peningkatan kejadian skabies.

\section{j. Ventilasi}

Hasil analisis bivariat terhadap variabel ventilasi menunjukkan bahwa ventilasi memengaruhi kejadian penyakit skabies pada santri di Pondok Pesantren Qotrun Nada tahun ajaran 2015/2016, dengan $\mathrm{p}$ value sebesar $0,001(\mathrm{p}<0,05)$. Ruangan dengan ventilasi yang kurang berfungsi dapat memengaruhi kualitas sirkulasi udara di ruangan tersebut. Kondisi inilah yang menjadi peluang bagi Sarcoptes scabiei untuk berkembang biak.

Hal ini sejalan dengan penelitian Lathifa (2014, hlm. 68) yang menyebutkan bahwa ventilasi kamar tidur merupakan salah satu parameter yang paling berperan dalam penularan penyakit skabies. Hal ini juga didukung dengan penelitian Kuspriyanto (2013, hlm.13) yang menyebutkan bahwa terdapat hubungan bermakna antara ventilasi dengan kejadian penyakit skabies.

\section{Hasil Analisis Multivariat}

\begin{tabular}{lc} 
Tí & \multicolumn{1}{c}{ Variabei } \\
\hline Pengetahuan & Epx (B) \\
\hline Sikap & 1,373 \\
\hline Perilaku & 1,485 \\
\hline Kepadatan Penghuni & 0,613 \\
\hline Kelembaban Udara & 15,000 \\
\hline Pencahayaan Alami & 5,777 \\
\hline Suhu & 5,777 \\
\hline Ventilasi & 3,960 \\
\hline Sumber: Data primer 2016 & 11,25 \\
\hline
\end{tabular}

Dari tabel 4 di atas, diketahui bahwa kekuatan hubungan yang terbesar untuk variabel karakteristik santri adalah variabel sikap, yaitu sebesar 1,485 . Kekuatan hubungan yang terbesar untuk variabel lingkungan fisik kamar santri adalah variabel kepadatan penghuni.

\section{a. Pengetahuan}

Hasil analisis multivariat menunjukkan bahwa santri dengan pengetahuan yang kurang 1,82 kali lebih berisiko terhadap kejadian skabies daripada santri dengan pengetahuan yang cukup atau baik. Variabel ini merupakan variabel ketiga yang berpengaruh terhadap kejadian penyakit skabies, setelah perilaku dan sikap.

Hasil analisis multivariat ini sejalan dengan teori perilaku menurut Lawrence Green (1990) yang menyebutkan bahwa pengetahuan dapat memengaruhi sikap yang kemudian dibenarkan dengan perilaku dari seseorang. Determinan perilaku ditentukan oleh beberapa faktor, salah satunya yaitu pengetahuan.Apabila pengetahuan mengenai skabies minim, maka akan memengaruhi santri dalam bersikap yang selanjutnya memengaruhi perilaku santri terhadap pencegahan skabies, karena pengetahuan merupakan domain yang sangat penting dalam membentuk perilaku seseorang (Notoatmodjo 2007, hlm.139).

\section{b. Sikap}

Hasil analisis multivariat menunjukkan bahwa santri dengan sikap kurang 1,937 kali lebih berisiko terhadap kejadian skabies daripada santri dengan sikap cukup atau baik. Variabel ini merupakan variabel kedua yang berpengaruh terhadap kejadian penyakit skabies, setelah perilaku. Hal ini dikarenakan sikap dapat dipengaruhi oleh pengetahuan, yang kemudian dibenarkan dengan tindakan atau perilaku dari seseorang. Apabila sikap mengenai skabies minim, maka akan berpengaruh terhadap perilaku santri dalam pencegahan skabies (Notoatmodjo 2007, hlm.142)

\section{c. Perilaku}

Hasil analisis multivariat menunjukkan bahwa santri dengan perilaku kurang 2,418 kali lebih berisiko terhadap kejadian skabies daripada santri dengan perilaku cukup atau baik. Variabel ini merupakan variabel pertama yang berpengaruh terhadap kejadian penyakit skabies. Hal ini dikarenakan perilaku yang kurang dapat memberikan peluang bagi agen Sarcoptes scabiei untuk datang pada pejamu. Selain itu, masih banyaknya santri yang tidak memperhatikan perilaku kebersihan dirikarena hal-hal seperti ini dianggap tergantung kebiasaan seseorang. Probabilitas santri yang memiliki perilaku baik terhadap kejadian penyakit skabies yaitu sebesar 
$31,6 \%$, sedangkan santri yang memiliki perilaku kurang mengenai skabies terhadap kejadian penyakit skabies yaitu sebesar 52,6\%. Hal ini menunjukkan bahwa perlu adanya pengarahan dan pembelajaran bagi santri terhadap perilaku yang masih minim dalam pencegahan penyakit scabies agar dapat meminimalisir kejadian penyakit skabies di pesantren tersebut.

\section{d. Kepadatan Penghuni}

Hasil analisis multivariat menunjukkan bahwa kepadatan penghuni pada kamar yang tidak memenuhi syarat kesehatan berisiko 15 kali lebih besar terhadap kejadian penyakit skabies dibandingkan kamar santri yang memenuhi syarat kesehatan. Oleh karena hal tersebut, perlu adanya tindak lanjut terhadap kepadatan penghuni pada kamar santri dengan memberikan tempat huni yang memenuhi syarat sesuai dengan Permenkes, yaitu dengan penambahan jumlah ruang kamar untuk mengurangi kepadatan penghuni pada kamar santri.

Probabilitas kepadatan penghuni kamar yang memenuhi syarat kesehatan sehingga berdampak terhadap kejadian penyakit skabies yaitu sebesar $12,6 \%$. Angka ini memberikan peluang bagi santri untuk terhindar dari penyakit skabies, sedangkan probabilitas kepadatan penghuni kamar yang tidak memenuhi syarat kesehatan yang dapat berdampak terhadap kejadian skabies yaitu sebesar 68\%. Hal ini menunjukkan bahwa perlu adanya perlakuan terhadap kondisi lingkungan fisik kamar santri agar kedepannya dapat meminimalisir kejadian penyakit skabies di pesantren tersebut.

\section{e. Kelembaban Udara}

Hasil analisis multivariat menunjukkan bahwa kelembaban udara pada kamar yang tidak memenuhi syarat kesehatan berisiko 2,924 kali lebih besar terhadap kejadian penyakit skabies dibandingkan kamar santri yang memenuhi syarat kesehatan.

Oleh karena hal tersebut, perlu adanya tindak lanjut terhadap kelembaban udara pada kamar santri dengan memberikan tempat huni yang memenuhi syarat sesuai dengan Permenkes, yaitu dengan maksimalisasi fungsi ventilasi yang sudah ada, untuk dijadikan media sirkulasi udara sebagaimana mestinya dan didukung oleh faktor-faktor lain yang memengaruhi kelembaban.

\section{f. Suhu}

Hasil analisis multivariat menunjukkan bahwa suhu pada kamar yang tidak memenuhi syarat kesehatan berisiko 0,851 kali lebih besar terhadap kejadian penyakit skabies dibandingkan kamar santri yang memenuhi syarat kesehatan. Suhu yang tidak sesuai dengan syarat kesehatan, dapat berdampak pada meningkatnya kejadian penyakit skabies.Sebagian besar cahaya yang masuk ke dalam kamar santri tidak sesuai dengan syarat kesehatan, yang selanjutnya akan memengaruhi suhu. Suhu menjadi rendah dalam ruangan tersebut, kelembaban meningkat yang mana berpengaruh terhadap perkembangbiakan Sarcoptes scabiei.

\section{g. Ventilasi}

Hasil analisis multivariat menunjukkan bahwa ventilasi pada kamar yang tidak memenuhi syarat kesehatan berisiko 1,605 kali lebih besar terhadap kejadian penyakit skabies dibandingkan kamar santri yang memenuhi syarat kesehatan. Oleh karena itu, perlu adanya perbaikan bagi maksimalisasi fungsi dari ventilasi agar digunakan sebagaimana mestinya.

\section{KETERBATASAN PENELITIAN}

a. Keterbatasan yang dialami peneliti menyangkut perizinan untuk melaksanakan penelitian dalam pengambilan data.Pada perizinan masih ditemui birokrasi yang cukup membutuhkan waktu sehingga memperpanjang lamanya penelitian.

b. Variabel perilaku tidak diobservasi, hanya ditanyakan melalui kuesioner karena keterbatasan waktu. Instrumen penelitian menggunakan kuesioner dimana bersifat subjektif dan rentan akan ketidakjujuran responden dalam pengisiannya.

c. Beberapa responden yang tidak dapat hadir pada saat pengambilan data, sehingga data yang didapatkan tidak sesuai dengan besar sampel yang dialokasikan. 


\section{KESIMPULAN}

Berdasarkan hasil analisis dan pembahasan terhadap hasil penelitian yang diperoleh, maka dapat diambil kesimpulan sebagai berikut:

a. Prevalensi kejadian penyakit skabies di Pondok Pesantren Qotrun Nada sebesar $52,3 \%$

b. Tidak adahubungan antara jenis kelamin santri dengan kejadian penyakit skabies

c. Tidak adahubungan antara usia santri dengan kejadian penyakit skabies

d. Ada hubungan antara pengetahuan santri dengan kejadian penyakit skabies

e. Ada hubungan antara sikap santri dengan kejadian penyakit skabies

f. Ada hubungan antara perilaku santri dengan kejadian penyakit skabies

g. Ada hubungan antara kepadatan penghuni kamar santri dengan kejadian penyakit skabies

h. Ada hubungan antara kelembaban udara kamar santri dengan kejadian penyakit skabies

i. Ada hubungan antara pencahayaan alami kamar santri dengan kejadian penyakit skabies

j. Ada hubungan antara suhu kamar santri dengan kejadian penyakit skabies

k. Ada hubungan antara ventilasi kamar santri dengan kejadian penyakit skabies

1. Karakteristik santri yang paling dominan dalam memengaruhi kejadian penyakit skabies adalah sikap santri. Variabel lingkungan yang paling dominan dalam memengaruhi kejadian penyakit skabies adalah kepadatan penghuni pada kamar santri Pondok Pesantren Qotrun Nada

\section{SARAN}

a. Bagi Departemen Agama Depok, dapat memberikan kebijakan mengenai peraturan fasilitas infrastruktur pondok pesantren di Depok

b. Bagi Pondok Pesantren Qotrun Nada, diharapkan dapat memberikan informasi lebih lanjut tentang kejadian skabies melalui penyuluhan bekerja sama dengan Puskesmas Cipayung, mengenai PHBS, personal hygiene terkait skabies, dan penyakit skabies dan mulai men- erapkan perilaku kebersihan diri dengan baik untuk mencegah penularan penyakit skabies

c. Bagi santri, perlu meningkatkan pengetahuan dan perilaku pencegahan skabies dengan menjaga kebersihan lingkungan

d. Pada penelitian selanjutnya mengenai skabies, dapat menambah variabel yang berbeda, seperti dari aspek sosial ekonomi, pendapatan keluarga, dan lain-lain

\section{DAFTAR PUSTAKA}

Adiyaningsih, Tuti, Faisal Asdar, H. Ismail 2012, 'Faktor-faktor yang berhubungan dengan kejadian penyakit scabies di poliklinik balai pendidikan dan pelatihan ilmu pelayaran (BP2IP) barombong', Jurnal STIKES Nani Hasanuddin Makassar, vol.1, no.2, 2012, hlm. 6.

Akmal, SC, Rima Semiarty, Gayatri 2013, 'Hubungan personal hygiene dengan kejadian skabies di pondok pendidikan islam darul ulum, palarik air pacah, kecamatan koto tangah padang tahun 2013', Jurnal Kesehatan Andalas, vol.2, no.3, 2013, hlm. 165-166.

Al Audhah, N, Sitti, RU, Agnes, SS 2012, 'Scabies risk factor on students of islamic boarding school (study at darul hijrah islamic boarding school, cindai alus village, martapura subdistrict, banjar district, south kalimantan', Jurnal Buski, vol.4, no.1, Juni 2012, hlm. 15-19.

Corrie 2001, Survei epidemiologi sederhana, Fakultas Kedokteran Universitas Indonesia, Jakarta.

Djuanda, A dkk. 2007, Ilmu penyakit kulit dan kelamin edisi V, Badan Penerbit Fakultas Kedokteran Universitas Indonesia, Jakarta.

Efendi, Ferry 2009, Keperawatan kesehatan komunitas: teori dan praktik dalam keperawatan, Salemba Medika, Jakarta.

Handoko, RP 2008, Skabies: ilmu penyakit kulit dan kelamin edisi V, Fakultas Kedokteran Universitas Indonesia, Jakarta.

Harahap, Marwali 2008, Ilmu penyakit kulit, Gramedia, Jakarta. 
Hilma, UD \& Ghazali L 2014, 'Faktor-faktor yang mempengaruhi kejadian skabies di pondok pesantren mlangi nogotirto gamping sleman yogyakarta, JKKI, vol.6, no.3, SeptemberDesember 2014, hlm. 150.

Hungu 2007, Demografi kesehatanIndonesia, Penerbit Grasindo, Jakarta.

Indonesia. Departemen Kesehatan Republik Indonesia 2009, Kesehatan, Direktorat Jenderal, Jakarta.

Windi, N.I.H 2014, Hubungan karakteristik, faktor lingkungan, dan perilaku dengan kejadian skabies di pondok pesantren darul amanah desa kabunan kecamatan sukorejo kabupaten kendal, Skripsi, Universitas Dian Nuswantoro.

Kuspriyanto 2013, 'Pengaruh sanitasi lingkungan dan perilaku sehat santri terhadap kejadian skabies di pondok pesantren kabupaten pasuruan jawa timur, Jurnal Geografi, vol.11, no.21, Oktober 2013, hlm.13.

Lathifa, Mushallina 2014, Faktor-faktor yang berhubungan dengan suspect skabies pada santriwati pondok pesantren modern diniyyah pasia, kecamatan ampek angkek, kabupaten agam, sumatera barat tahun 2014, Skripsi, Universitas Islam Negeri Syarif Hidayatullah.

Mandal, BK dkk. 2009, Lecture notes:penyakit infeksi edisi keenam, Erlangga, Jakarta.

Najmah 2015, Epidemiologi untuk mahasiswa kesehatan masyarakat, Rajawali Press, Banten.

Noor 2014, Pengantar epidemiologi penyakit menular, Rineka Cipta, Jakarta.

Notoatmodjo, S 2007, Ilmu perilaku kesehatan, PT Rineka Cipta, Jakarta.

2010, Metodologi penelitian kesehatan, Rineka Cipta, Jakarta.

Nugraheni, DN 2008, Pengaruh sikap tentang kebersihan diri terhadap timbulnya skabies (gudik) pada santriwati di pondok pesantren al-muayyad surakarta, Skripsi, Universitas Muhammadiyah Surakarta.
Pondok Pesantren Qotrun Nada 2016, Profil pondok pesantren qotrun nada, Pondok Pesantren Qotrun Nada, Depok.

Ratnasari, AF \& Saleha, S 2014, 'Prevalensi Skabies dan Faktor-faktor yang Berhubungan di Pesantren X, Jakarta Timur', eJKI, vol.2 no.1, April 2014, hlm. 2, 254. 